\title{
Geochemical characteristics and geological significance of the adakites from west Tibet
}

\author{
Cai Zhiyong\#*, Qiu Ruizhao§ and Xiong Xiaolingł \\ † Guangzhou Institute of Geochemistry, Chinese Academy of Sciences, Guangzhou 510640, CHINA \\ ¥ Northwestern Hubei Survey of Geology and Mineral Resources, Xiangfan, 441003, CHINA \\ $\$$ Institute of Geology, Chinese Academy of Geological Sciences, Beijing 100037, CHINA
}

*Towhom correspondence should be addressed.E-mail:zhiyongcai@vip.sina.com

The occurrences of adakite or adakite-like rocks in the eastern part of the Qinghai-Tibetan region are well known (Qu et al. 2002, Hou et al.2003). Here, we report the first occurrence of such rocks from the western part. The geochemical characteristics of adakite distributed in the west Tibet (between $88^{\circ}$ longitudes and the western borders of China) and of less than $25 \mathrm{Ma}$ in age are presented in this paper. The geological significance of the adakites is also discussed by comparing with the adakite-like rocks exposed in the east.

Samples for geochemical study were taken from 3 sites from the southern, middle and northern Gangdese plutons where the trends are generally NNE. These samples, which belong to the series of continental alkaline magmatism, have the following characteristics: relatively high $\mathrm{Si}_{2}(56.00 \sim 71.51 \%)$ and $\mathrm{Al}_{2} 0_{3}$ (13.04 16.85\%) and $\mathrm{Na}_{2} \mathrm{O}\left(\mathrm{Na}_{2} \mathrm{O} / \mathrm{K}_{2} \mathrm{O}=1.2\right.$ to 2.4$)$; high $\mathrm{Mg}^{\#}$ ratios (57 64) based on petrochemistry; high $\mathrm{Sr}$ (420 1068 ppm); lowY (3.32 16.7 ppm). They show a REE pattern rich in light REE and abnormality in $\mathrm{Eu}$ (weak) and $\mathrm{Sr}$ (positive) compared to the standardized pattern. These geochemical characteristics are typical of adakite according to Defant and Drummond (1990) (Figure 1).

Considering the isotopic age of the samples as less than 25 Ma and a crustal thickness of the Tibetan crust reached to $60 \mathrm{~km}$ at that time based on petrologic evidence (Qiu 2002), it is suggested that the subducted oceanic crust slab was not involved in producing adakite magmas, which formed these rocks. So they probably belong to C-type adakite (Zhang et al. 2001), which were derived from the partial melting of the lower thickened crust.

Most of the plutons, which host the adakites, show with NNE trends. The direction of shortening of the crust is $\mathrm{SN}$ whereas the extension occurred along an EW direction. Hence, the adakites from west Tibet are probably genetically related to the development of a rift along $\mathrm{SN}$ direction.

It is well known that $\mathrm{Cu}$ deposits are closely related to adakite in China as well as abroad. Also reported are the occurrences of many copper deposits in and around the cotemporaneous adakite or adakite-like rocks in eastern part of the Qinghai-Tibetan Plateau (Qu et al. 2002, Hou et al. 2003). Therefore, the discovery of the Cenozoic adakite implies to the brilliant prospect for new copper deposits in the western part of Qinghai-Tibetan Plateau.

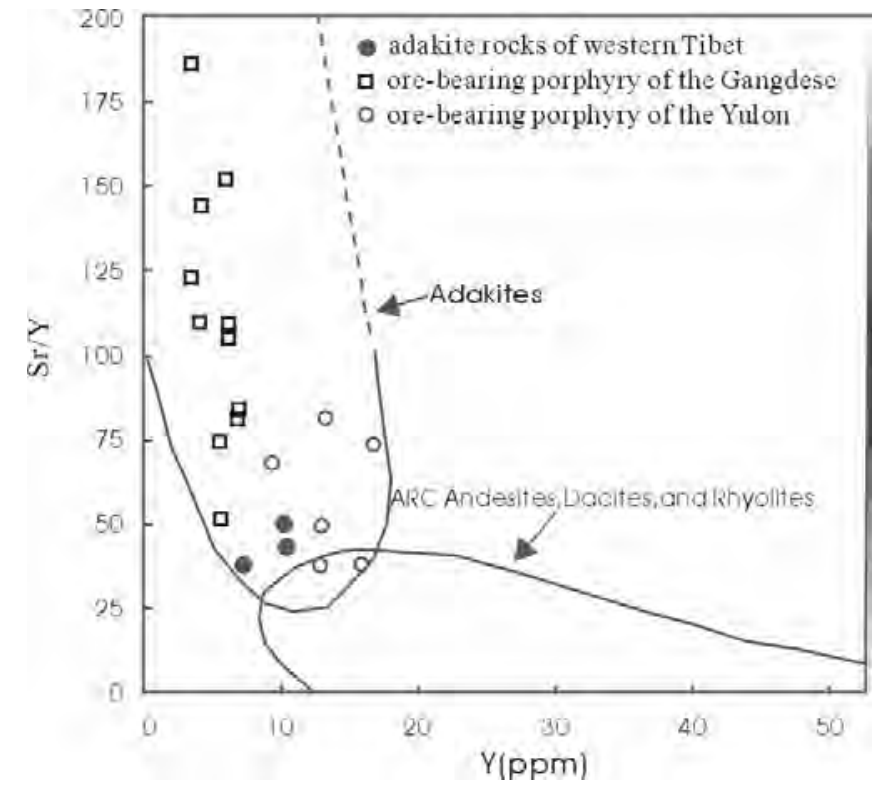

FIGURE 1. Y vs Sr/Y plot for adakite like rocks from the Tibetan plateau

References

Defant MJ and Drummond, MS. 1990. Derivation of some modern arc magmas by melting of young subduction lithosphere. Nature 347 : $662 \sim 665$

Hou ZQ, Mo XX, and Gao YF. 2003. Adakite, a possible host rock for porphyry copper deposits: case studies of porphyry copper belts in Tibetan Plateau and in Northern Chile. Mineral Deposits, 1(22): 1-12

Qiu Ruizhao. 2002. Igneous rocks and tectonic evolution of the Neo-tethyan in the western Tibetan Plateau [dissertation], Beijing: China University of Geosciences: $100 \mathrm{p}$

Qu XM, Hou ZQ, and Li YG. 2002. Implications of S and Pb isotopic compositions of the Gangdise porphyry copper. Geological bulletin of china 21(11): 768-776

Zhang Q, Wang Y, Qian Q, Yang JH, Wang YL, Zhao TP, Guo GJ. 2001. The chatacteristics and tectonic-metallogenic significances of the Mesozoic adakitic rocks in eastern China. Acta Petrologica Sinica 17: 236-244 